\title{
A synopsis of the species of Mesovelia (Insecta: Heteroptera: Mesoveliidae) occurring in the floodplain of the Amazon River, Brazil, with redescriptions of Mesovelia mulsanti White and M. zeteki Harris \& Drake
}

Felipe Ferraz Figueiredo MOREIRA¹, José Ricardo Inacio RIBEIRO², Jorge Luiz NESSIMIAN³

\begin{abstract}
Mesovelia mulsanti White, 1879 and M. zeteki Harris \& Drake, 1941 are newly recorded in the Amazon River floodplain, Brazil. A key to the three known species ocurring in this region is also provided. Mesovelia mulsanti can be distinguished from $M$. amoena and $M$. zeteki by the body length larger than $2.50 \mathrm{~mm}$, the head without longitudinal brown stripes near midline, and the forefemur and midfemur of the male, which have ventral rows of spines. Mesovelia amoena differs from M. zeteki in aspects of body color and in number of spinules near posterior margin of abdominal sternite VI of male.
\end{abstract}

KEYWORDS: aquatic insects, Gerromorpha, Neotropics, Amazonia.

\section{Sinopse das espécies de Mesovelia (Insecta: Heteroptera: Mesoveliidae) ocorrentes na várzea do Rio Amazonas, Brasil, com redescrições de Mesovelia mulsanti White e M. zeteki Harris \& Drake}

\begin{abstract}
RESUMO
Mesovelia mulsanti White, 1879 e M. zeteki Harris \& Drake, 1941 são registradas pela primeira vez na várzea do Rio Amazonas. Uma chave de identificação para essas espécies é fornecida. Os espécimes de $M$. mulsanti podem ser diferenciados dos das demais espécies pelo tamanho do corpo maior que $2,50 \mathrm{~mm}$, pela ausência de faixas marrons longitudinais próximas à porção mediana da cabeça e pela presença de uma fileira ventral de espinhos nos fêmures anteriores e medianos dos machos. Mesovelia amoena diferencia-se de $M$. zeteki em termos de coloração do corpo e do número de espinhos próximos à margem posterior do sexto esternito abdominal dos machos.
\end{abstract}

PALAVRAS-CHAVE: Gerromorpha, insetos aquáticos, Região Neotropical, Amazônia.

\footnotetext{
1 Universidade Federal do Rio de Janeiro/Instituto de Biologia, Departamento de Zoologia, Laboratório de Entomologia felipento@hotmail.com

2 Universidade Federal de Santa Maria, belostom@acd.ufrj.br

${ }^{3}$ Universidade Federal do Rio de Janeiro/ Instituto de Biologia, Departamento de Zoologia, Laboratório de Entomologia, nessimia@acd.ufrj.br
} 


\section{INTRODUCTION}

The Amazon River floodplains (locally called várzea) occupy more than $100,000 \mathrm{~km}^{2}$ in area, including small tributaries, open water lakes, floating meadows and great extensions of seasonally flooded forests. These floodplains shelter highly diverse biota and productivity, and a rich heteropteran fauna is represented (Goulding et al., 2003; Nessimian et al., 2004).

The family Mesoveliidae is a group of small to moderate sized bugs generally found on the vegetation or on the surface of calm water collections, although some species may be considered terrestrial or semi-terrestrial. Four of the twelve known genera occur in South America: Cryptovelia Andersen \& Polhemus, 1980; Darwinivelia Andersen \& Polhemus, 1980; Mesovelia Mulsant \& Rey, 1852; and Mesoveloidea Hungerford, 1929 (Andersen \& Polhemus, 1980). Only Mesovelia species have previous records in the Amazon River floodplain. Cryptovelia is found on forest soil in the state of Pará, Brazil; Darwinivelia occurs on water retained on rocky shores in the Galapagos Islands and Pará; and Mesoveloidea have hygropetric preferences, being found from Mexico south to the state of Rio de Janeiro, Brazil (Andersen e Polhemus, 1980; Carvalho, 1984; Moreira et al., 2006).

In this paper we present a survey of the Mesovelia from the Amazon River floodplain, new records, a key to the represented species and the redescription of two of the three occurring species, since the original descriptions are deficient.

\section{MATERIAL AND METHODS}

The studied area includes 26 localities in the floodplain of the Amazon River in Brazilian territory, between the municipalities of Tabatinga, State of Amazonas, and Gorupá, State of Pará. Examined material was collected associated with floating plants of the genus Eichhornia or on U.V. light traps positioned near the water.

Deposition of the specimens was made in the entomological collections of the Instituto Nacional de Pesquisas da Amazônia (INPA) and the Departamento de Zoologia, Universidade Federal do Rio de Janeiro (DZRJ). Additional material from the DZRJ and the Museu Nacional do Rio de Janeiro (MNRJ) was observed, providing new records from other localitites in Brazil, which are presented in the distribution sections below each species section.

Identification of specimens was based on Spangler (1990). Nomenclature of structures and measurements (partially) followed Andersen e Polhemus (1980). Measurements were made from five males and five females whenever possible and given in millimeters. Illustrations were prepared on a stereoscopic microscope with a camera lucida. Maps were made with the software Arcview 3.2a (Moretti e Francelino, 2003).

In quotations of label data, a comma separates different information, a period separates information on different specimens, and a semicolon separates different specimens with same information. In the distribution section, municipalities appear in bold letters and new locality records are marked with an exclamation mark. Names of collectors or deposition institutes appear in parentheses. Other abbreviations used: British Museum of Natural History (BMNH); United States National Museum (USNM); Carl J. Drake Collection (CJD), now in USNM.

\section{RESULTS AND DISCUSSION}

Three species of Mesovelia were recorded in the studied area: M. amoena Uhler, 1894; M. mulsanti White, 1879; and M. zeteki Harris \& Drake, 1941. Specimens of the last two species were redescribed, as the original descriptions are inaccurate. Although specimens of $M$. amoena from the várzea were not observed, it occurs in the region and the original description is included.

\section{Mesovelia amoena Uhler, 1894}

Mesovelia amoena Uhler, 1894: 218.

Mesovelia douglaensis Hungerford, 1924: 142. [synonym determined by Jaczewski (1930)]

\section{Types}

Female syntypes: Mount Maitland and Mount Gay, Grenada (BMNH, USNM).

\section{Original description}

"Dark brown, almost black in some specimens; beneath pale brown with a plumbeous tinge, except the venter, which is yellow with transverse cloudings of darker colour on the segments, sides, and tip. Head broader in the female than in the male, obscure yellow, the vertex with a brown stripe each side and the middle line grooved, the tylus and borders of cheeks piceous; antennae long and slender, rusty brown, paler on the basal portion of the first joint, the second joint about two thirds the length of the first and not as thick, the following joints long and more slender; rostrum testaceous, piceous at base and tip, reaching between the middle coxae. Pronotum opaque, velvety brown, marked with a whitish transverse spot on the middle of the collum; the posterior margin widely sinuated; the lateral margin with the carinate edge but slightly elevated, marked with two or three small pale spots; the humeral margins more distinctly reflexed. Scutellum almost black, a little rough, opaque. Coxae and legs ivory whitish, more or less infuscated on the tibia and 
tarsi. Pleural pieces more or less tinged with plumbeous on a brown ground. Hemelytra velvety brown, opaque, the base and a long streak each side white; behind the white band the surface is pale brown, and behind this including the posterior part of the membrane, it is pale smoke-brown; the base of the membrane and a stripe at its tip obscure whitish. Venter glossy, often with a dark stripe each side near the lateral border.

Length to tip of venter $2 \mathrm{~mm}$.; width of pronotum $3 / 4$ mm."

\section{Comments}

The color of the specimens of this species is brown instead of the greenish or yellow of most Mesovelia. They have roughly half the body length of that of $M$. mulsanti (1.80 to 2.10 $\mathrm{mm}$ ), but are robust in relation to other species of the genus (Polhemus e Chapman, 1979). Individuals from the state of Minas Gerais (Brazil) seen by Nieser e Melo (1997), however, range from 2.00 to $2.50 \mathrm{~mm}$.

Jaczewski (1930) assumed that $M$. douglaensis Hungerford, 1924 probably is a synonym of $M$. amoena, but did not compare males of the two species, as pointed out by Hungerford (1953). Posteriorly the synonym could be confirmed, as seen in Spangler (1990).

Specimens of $M$. amoena can be distinguished from other Neotropical Mesovelia by the following male features: absence of spines on fore and middle femora, abdominal sternite VI without fringe of black spinules and anterior lobe of pronotum with distinct depression on each side of median line. The rostrum can be longer than determined by Uhler in the original description, reaching up to the apex of the hind coxa (Jaczewski, 1930).

\section{Notes on biology}

Representatives of $M$. amoena generally occur on moss covered rocks and rock crevices in springs, or in ponds with aquatic plants. They have more cryptic habits than $M$. mulsanti, rarely being collected in open waters (Herring, 1950), feeding on small insects that fall in the water or ostracodans that swim up to the water surface (Hoffman, 1932). According to Cobben (1960) and Gagné e Howarth (1975), the species is parthenogenetic in the tropics and in Hawaii, since males from these areas were unknown to them. Material observed from the DZRJ and MNRJ collections was of females only.

\section{Distribution (Fig. 13)}

The species is known from southern Canada (Hungerford, 1953), several localities on the continental United States of America (Blatchley, 1926; Herring, 1950; Hungerford, 1953; Polhemus e Chapman, 1979; Spangler, 1990), México, Dominican Republic (Spangler, 1990), Puerto Rico (Harris e Drake, 1941), Belize, Bonaire (Spangler, 1990), Grenada (Uhler, 1894a), Curaçao, Costa Rica (Spangler, 1990), Panama (Harris e Drake, 1941), and Trinidad and Tobago (Harris e Drake, 1941; Bass, 2003). It was also introduced in Hawaii (Andersen e Polhemus, 1980).

Distribution in Brazil: Pará (Harris e Drake, 1941) - Paragominas!, Parauapebas!; Amazonas - Presidente Figueiredo, Manaus (Pereira, 2004); Rondônia - Ji-Paraná!; Minas Gerais - Januária (Melo e Nieser, 2004), Bocaiúva, Gouveia, Perdizes, Conceição das Alagoas, Uberaba, Sete Lagoas, Belo Horizonte (Nieser e Melo, 1997), Brumadinho (Vianna e Melo, 2003), Mariana (Souza et al. 2006), Ouro Branco, São Vicente de Minas, Alfenas; Espírito Santo; (Nieser e Melo, 1997); Rio de Janeiro - Macaé!, Teresópolis!; São Paulo - Ubatuba!

\section{Examined Material from the Amazon River floodplain}

No individuals of the species were examined during the preparation of the present paper. However, it is quite common and there are previews records in the states of Amazonas and Pará, which lead to its inclusion in the study.

\section{Additional material}

BRAZIL: Pará - Paragominas, 16.I.2001, (N. FerreiraJr.): 1 apterous female (DZRJ) [Capim River]. Parauapebas, FLONA Carajás, Serra Norte, (N. Ferreira-Jr.): 28.IX.2005, 1 apterous female (DZRJ) [buritizal, marginal pond with litter]; 10.IX.2006, (N. Ferreira-Jr. \& L. L. Dumas): 1 apterous female (DZRJ); Serra Sul, 01-02.III.2005, (N. Ferreira-Jr.): 1 macropterous female and 1 apterous female (DZRJ) [06 05' 50" S / 50 07' 50,1" W]; III.2005: 1 apterous female (DZRJ) [0575319 / 9292210]. Rondônia - Ji-Paraná, III.1983, (Equipe J. R. Arias): 1 macropterous female (MNRJ). Rio de Janeiro - Macaé, 16.VIII.2001, (N. Ferreira-Jr.): 5 apterous female and 1 nymph (DZRJ); 16.IV.2002: 1 apterous female (DZRJ); 29.VII.2003: 1 apterous female, 1 female with broken wings and 1 nymph (DZRJ); 28.VII.2004: 6 females with broken wings, 1 apterous female and 1 nymph (DZRJ) [Macaé River]; 12.VII.2006: 1 female with broken wings (DZRJ) [Macaé River]; Barra do Sana, 13.VII.2000, (R. M. C. Paiva): 2 apterous females (DZRJ) [pool]. Teresópolis, 16.VI.1991, (J. L. Nessimian), F. F. F. Moreira det. 2007: 2 apterous females (DZRJ) [Açude da Inglesa]. São Paulo 
- Ubatuba, Parque Estadual da Serra do Mar, Núcleo Picinguaba, 19.VI.2004: 1 apterous female (DZRJ).

Mesovelia mulsanti White, 1879

Mesovelia mulsanti White, 1879: 268.

Mesovelia bisignata Uhler, 1884: 274 [synonym determined by Champion (1898)].

Mesovelia. mulsanti mulsanti White, 1879: 269 [assigned as subspecies by Jaczewski (1930); synonym determined by Herring (1950)]

Mesovelia mulsanti bisignata Uhler, 1884: 274 [assigned as subspecies by Jaczewski (1930); synonym determined by Herring (1950)]

Mesovelia mulsanti meridionalis Jaczewski, 1930: 6 [synonym determined by Herring (1950)].

Mesovelia mulsanti caraiba Jaczewski, 1930: 6 [synonym determined by Herring (1950)].

\section{Types}

Female syntypes: Purus River, Amazonas, Brazil (BMNH).

\section{Redescription}

Macropterous male

Body length-2.81-3.16; body width across humeri0.81-0.89; head length in lateral view-0.70-0.75; head width across eyes- $0.61-0.65$; length of antennal joints (intersegmental pieces not included): I-0.48-0.55, II-0.38-0.44, III-0.64-0.71, IV-0.74-0.88; minimum interocular distance $-0.21-0.25$; eye width $-0.16-0.24$; length of pronotum on midline- $0.61-0.65$; wing length (broken off) - 1.29-1.45; foreleg length: femur - 0.75-0.90, tibia $-0.70-0.75$, tarsomerus $\mathrm{I}-0.05-0.06$, tarsomerus II-0.09-0.13, tarsomerus III-0.13-0.14; midleg length: femur-1.08-1.13, tibia $-0.99-1.10$, tarsomerus I-0.050.06 , tarsomerus II-0.16-0.23, tarsomerus III-0.15-0.20; hindleg length: femur-1.28-1.50, tibia-1.75-1.86, tarsomerus I-0.06-0.08, tarsomerus II-0.26-0.29, tarsomerus III-0.18-0.21.

Most of body yellow, with venter lighter than dorsum. Head dark yellow with trichobotria inserted in depressions bordered by dark brown; antennal joint I yellow; apex of antennal joint II and joints III and IV light brown; eyes reddish brown; ocellus with internal part dark brown and external part yellow; most of rostrum yellow, with joint IV brown. Pronotum with small dark brown collar behind head; anterior third of pronotum yellow with two oblique brown impressions; rest of pronotum dark brown with yellow median line and two light marks, one next to each humeri; posterior margin darker than rest of pronotum; scutellum with two crescent-shaped brown lateral marks; metanotal elevation mostly dark brown to black; forewing whitish with light brown veins; apical joints of legs darker than basal joints; tarsomerus I and III brown and tarsomerus II pale yellow in all legs.

Body somewhat long and thin. Head anteriorly extended, covered by short black pubescence and some longer black setae on lateral areas, besides cephalic trichobotria; antennae long and thin, reaching up to or slightly passing humeri; antenna covered by light brown setae and one longer and robust seta on apical fourth of joint I; antennal joint I slightly curve, wider than others; antennal joints II and III cylindrical; antennal joint IV fusiform; rostrum long, reaching metacoxa. Pronotum with small anterior collar behind head, followed by anterior band with two shallow lateral impressions; fine black setae present on pronotum, more abundant on anterior band; posterior band of pronotum with small central elevation and depressed near humeri; humerus slightly elevated with rounded margin; posterior margin of pronotum laterally rounded, becoming straight centrally; scutellum rounded and centrally elevated, with pair of lateral crescent-shaped depressions; metanotal elevation with posterior margin rounded; forewing with two long proximal cells and one small rounded distal cell; forewing may be broken off after cells; legs thin, covered by short brown setae and dorsal robust black setae near apex of femora - one on anterior, two on median, and two on posterior (Figs. 1, 4 and 7: RST); forefemur with ventral row of two to six small black spines (Fig. 1: SPI); foretibia and midtibia with many long brown setae on apical third (Figs. 1 and 4: LST); midfemur with ventral row of nine to thirteen black spines, which can be longer than that of forefemur (Fig. 4: SPI); hindfemur with no ventral spines; hindtibia with long black spines along its length (Fig. 7: SPI). Abdominal tergite VII with truncate posterior margin; abdominal tergite VIII with posterior margin slightly rounded; pre-genital abdomen ventrally glabrous unless by small brown setae on lateral areas; abdominal sternite VIII with two tufts of sharp small black spines densely grouped (Fig. 3: SPI); long pale setae on lateral of abdominal sternite VIII (Fig. 3: LST); proctiger with weak median carina and two spine-like lateral expansions (Fig. 9: CAR, EXP); many long light setae present on apical portion of proctiger (Fig. 9: LST); posterior margin of proctiger rounded; apex of pigophore with long light setae; claspers symmetrical (Fig. 9: CLA); clasper (Fig. 11), in dorsal view, with widened base, becoming thinner up to acute apex; external margin of clasper with reentrance next to base, followed by inward directed curve; internal margin of clasper sinuous.

\section{Macropterous female}

Body length-3.33-3.61; body width across humeri -0.90-0.93; head length in lateral view-0.81; head width across eyes- $0.61-0.71$; length of antennal joints 
(intersegmental pieces not included): $\mathrm{I}-0.46-0.53$, II -0.44 , III-0.65-0.73, IV-0.79-0.83; minimum interocular distance $-0.26-0.34$; eye width $-0.15-0.18$; length of pronotum on midline- $0.66-0.68$; wing length (broken off) $-1.40-1.50$; foreleg length: femur $-0.86-0.88$, tibia0.73 , tarsomerus I -0.06 , tarsomerus II -0.11 , tarsomerus III-0.14; midleg length: femur-1.13-1.14, tibia-1.061.08 , tarsomerus I- $0.06-0.08$, tarsomerus II $-0.20-0.21$, tarsomerus III-0.16-0.18; hindleg length: femur $-1.25-$ 1.34 , tibia $-1.66-1.75$, tarsomerus I- $0.06-0.08$, tarsomerus II $-0.28-0.31$, tarsomerus III $-0.18-0.23$.

Similar to the male in coloration and structure, except for one or two robust setae on antennal joint I; forefemur with a ventral row of two to eight small black spines; midfemur with a ventral row of six to thirteen black spines; midtibia may bear robust black seta near apex, similar to that of femora; abdomen widening to middle, than becoming thinner; absence of spines on abdominal sternite VIII; and presence of serrate ovipositor.

\section{Comments}

Mesovelia mulsanti mulsanti, M. m. bisignata, M. m. meridionalis and $M . m$. caraiba were proposed by Jaczewski (1930) based mainly on morphology of gonapophyses and distribution of populations. However, these subspecies were not considered valid by Herring (1950), decision with which various authors agreed (e.g. Neering, 1954; Polhemus e Spangler, 1979). According to Spangler (1990), the statuses of the subspecies still need revision.

Apterous individuals of this species are generally thinner than alate ones (Uhler, 1884), with both forms occurring in a same population (Hungerford, 1919). In relation to other species of the genus, $M$. mulsant $i$ has larger representatives, with body length longer than $3.00 \mathrm{~mm}$ (Jaczewski, 1930; Polhemus e Spangler, 1979), usually ranging from 3.80 to $4.00 \mathrm{~mm}$ (Blatchley, 1926; Herring, 1950). However, Nieser e Melo (1997) recorded specimens at least as long as 2.50 $\mathrm{mm}$. Specimens observed in this study vary from 2.81 to $3.61 \mathrm{~mm}$.

According to Hungerford (1917), the wing membrane of adults of Mesovelia is generally broken off through the friction of the hind tibia against the wings, probably with help of the leg spines (Jordan, 1951). The length of unbroken wings observed was larger than $2.00 \mathrm{~mm}$ and passed the apex of the genital segments. In this case, the central vein of the forewing is prolonged and curved, reaching the internal margin of the wing and the apex of the forewing has a central light brown stripe. There were no significant differences in measurements of forms with wings broken off or unbroken.
The variation found in number of midfemur spines of males (Fig. 4) agrees with the range of nine to fifteen defined by Spangler (1990). Besides, the species can also be diagnosed by the presence of two tufts of sharp small black spines densely grouped in abdominal sternite VIII of male (Fig. 3).

\section{Notes on biology}

Bugs of this species live on the shore or on floating vegetation of ponds, puddles or running fresh or brackish water up to 1,584 m (Uhler, 1884; Hungerford, 1917, 1919; Usinger, 1942; Herring, 1950; Cobben, 1960). There seems to be no special relation to any species or kind of macrophyte, being found, for example, associated with Pistia sp., Salvinia sp., Paspalum sp (Poi de Neiff e Neiff, 2006), and also Eichhornia sp.

None of the specimens studied was collected in light traps, which can be explained by the prevalence of forms with broken wings on studied populations, or simply by a probably low attraction to light.

\section{Distribution (Fig. 14)}

The species is known from southern Canada (Jaczewski, 1930; Neering, 1954; Zimmermann e Spence, 1989), several localities on the continental United States of America (Uhler, 1894a; Osborn e Drake, 1915; Hungerford, 1919; Blatchley, 1926; Jaczewski, 1930; Usinger, 1942; Herring, 1950; Neering, 1954; Chapman, 1959; Larsen e Olson, 1997; Zuellig et al., 2006), Mexico (Jaczewski, 1930; Champion, 1898; Hungerford, 1936), Cuba (Jaczewski, 1930), Jamaica (Neering, 1954), Dominican Republic (Kirkaldy e TorreBueno, 1909), Puerto Rico (Barber, 1923), American Virgin Islands, Guatemala, Belize, Honduras, Costa Rica (Neering, 1954), Panama (Champion, 1898), Guadeloupe (Kirkaldy e Torre-Bueno, 1909), St. Thomas (Jaczewski, 1930), St. Vincent (Uhler, 1893), Grenada (Uhler, 1894a), Trinidad and Tobago (Bass, 2003), Colombia (Pérez, 1988), Venezuela, Guiana, Peru, Bolivia, Paraguay (Neering, 1954) and Argentina (Jaczewski, 1930; López-Ruf et al., 2003; Poi de Neiff e Neiff, 2006). Like M. amoena, it was also introduced in Hawaii (Andersen e Polhemus, 1980). Distant (1910) recorded the species in India, but it was due to a misidentification (Kirkaldy e Torre-Bueno, 1909), so the record was not considered.

Distribution in Brazil: Amapá - Oiapoque!; Pará Almerim!, Afuá!, Parauapebas!; Amazonas - Manaus (Pereira, 2004), Itacoatiara!, Parintins!, Rio Purus (White, 1879); Mato Grosso - Sinop!; Bahia - Juazeiro!, Caetité!; Minas Gerais - Januária (Melo e Nieser, 2004), Perdizes, Uberaba, Martinho Campos Lagoa Santa, Sete Lagoas, Belo Horizonte (Nieser e Melo, 1997), Mariana (Souza et 
al., 2006), Carmo do Rio Claro!, Viçosa!; Rio de Janeiro - Itaocara!, Quissamã!, Macaé!, Maricá!, Niterói!, Rio de Janeiro!, Mangaratiba!; São Paulo - Ubatuba!; Paraná (Jaczewski, 1928).

\section{Examined material from the Amazon River floodplain}

BRAZIL: Pará - Afuá, Rio Três Irmãos, 08.IX.2003, (P. de Marco \& N. Ferreira-Jr.): 2 males with broken wings, 1 macropterous male, 2 females with broken wings (INPA) [lake/river $-0,42403^{\circ} /-51,40475^{\circ}$. Almerim, Nova Aramanduba, 07.X.2003, (P. de Marco \& N. FerreiraJr.): 1 female with broken wings (INPA) [lake $-1,17777^{\circ}$ / $-51,79407^{\circ}$. Amazonas - Itacoatiara, Lírio do Vale, 24.IX.2003, (P. de Marco \& N. Ferreira-Jr.): 1 male with broken wing (INPA) [Albano Lake, -2,41418 / -57,49993ㅇ]; Nossa Senhora do Perpétuo Socorro, 21.IX.2003: 1 male with broken wing (INPA) [Traíra Lake, -3,15998 / -59,32716 ${ }^{\circ}$; Ilha da Trindade, 22.IX.2003: 3 macropterous males, 1 female with broken wings (DZRJ) [lake, -3,32478 / -58,74241이. Parintins, Menino Deus, 25.IX.2003, (P. de Marco \& N. Ferreira-Jr.): 1 female with broken wings (INPA) [Comprido Lake $-2,49865^{\circ} /-56,49080^{\circ}$.

\section{Additional material}

BRAZIL: Amapá - Oiapoque, 15.V.1953, (Alvarenga): 1 macropterous female (MNRJ). Pará - Curionópolis, Serra Pelada, 20.III.2006, (N. Ferreira-Jr.): 4 apterous males and 6 apterous females (DZRJ) [riparian vegetation]. Parauapebas, FLONA Carajás, Serra Norte, III.2005, (N. Ferreira-Jr.): 1 macropterous male and 1 macropterous female (DZRJ) [UV light trap]. Mato Grosso - Sinop, R. Teles Pires, no date, (Alvarenga): 1 macropterous male (MNRJ). Bahia - Juazeiro, V. 1974, (J. C. M. Carvalho): 1 macropterous female (MNRJ). Caetité, Complexo Uranífero de Lagoa Real, 08-16.I.2000, (J. L. Nessimian \& D. F. Baptista): 1 apterous male and 1 apterous female (DZRJ). Minas Gerais - Carmo do Rio Claro, 12.1949, (J. C. M. Carvalho \& J. Becker): 1 female with broken wings (MNRJ). Viçosa, 21.VII.1957, (J. Becker): 2 apterous females (MNRJ). Rio de Janeiro - Itaocara, Sítio Bom Sossego, 24.VI.2004, (F. F. F. Moreira): 1 macropterous male, 2 apterous males, and 1 apterous females (DZRJ) [açude]. Macaé, Barra do Sana, 13.VII.2000, (R. M. C. Paiva): 1 apterous female [pool] (DZRJ). Maricá, 18.IX.1987: 1 apterous male (DZRJ). Mangaratiba, Reserva Ecológica Rio das Pedras, 31.V.2003, (J. R. I. Ribeiro): 2 macropterous females (DZRJ). Quissamã, 09.VI.2006, (A. M. Sanseverino): 3 apterous males, 2 aptrerous females and 18 nymphs (DZRJ) [Lagoa Barrinha, shore with algae near beach]. Niterói, Itaipu, 30.X.1960, (H. Schubart): 1 macropterous female and 1 female with broken wings (MNRJ). Rio de Janeiro, Ilha do Fundão, VI.1978, (R. I. Rios): 3 apterous females and 1 nymph [pool] (DZRJ); Unknown locality, 19.IX.1986, (A. L. Carvalho): 1 apterous male (DZRJ). São Paulo - Ubatuba, Parque Estadual da Serra do Mar, Núcleo Picinguaba, 2829.X.2004, (F. F. F. Moreira): 1 apterous male, 1 macropterous male, 4 apterous females and 1 nymph (DZRJ) [brejo].

Mesovelia zeteki Harris \& Drake, 1941

Types

Male holotype: Panama City, Panama (CJD).

\section{Redescription}

\section{Macropterous male}

Body length - 1.70-1.99; body width across humeri0.61-0.65; head length in lateral view-0.48-0.50; head width across eyes- $0.40-0.45$; length of antennal joints (intersegmental pieces not included): I-0.25-0.30, II-0.160.24 , III-0.55-0.58, IV-0.63-0.64; minimum interocular distance-0.19-0.21; eye width-0.13; length of pronotum on midline-0.38-0.41; wing length-1.38-1.54; foreleg length: femur $-0.49-0.51$, tibia $-0.48-0.51$, tarsomerus I-0.03, tarsomerus II-0.06-0.08, tarsomerus III-0.090.11 ; midleg length: femur $-0.54-0.63$, tibia $-0.60-0.70$, tarsomerus I-0.03-0.04, tarsomerus II-0.06-0.10, tarsomerus III-0.10-0.11; hindleg length: femur-0.750.81 , tibia - 0.95-1.00, tarsomerus I-0.03-0.04, tarsomerus II-0.13-0.14, tarsomerus III-0.13-0.14.

Most of body yellow, with venter lighter than dorsum. Head dark yellow with two median brown stripes extending from ocelli to frons, or just in a small area in front of eyes; cephalic trichobotria inserted in pits bordered by dark brown; antennal joint I dark yellow to light brown; other antennal joints brown; eyes reddish brown; ocellus with internal part dark brown and external part yellow; most of rostrum yellow, with joint IV brown. Pronotum with small brown collar behind head; anterior band of pronotum yellow to light brown with central yellow mark; rest of pronotum light brown to brown with median darker mark near the posterior margin; scutellum light brown to brown with posterior margin distinctly darker; metanotal elevation brown; forewing pale brown with whitish marks and light brown veins; apical third of forewing pale brown with white longitudinal stripe extending almost to the wing apex; apex of posterior femur, tibia and tarsi usually darker than other leg joints.

Body slightly widened to the middle of abdomen, becoming thinner after that. Head anteriorly prolonged, covered by short black pubescence and few longer black setae on frons and near eyes, besides cephalic trichobotria; antennae thin and very long, reaching the middle of abdomen; antenna covered by short dark setae and two longer robust 
setae after middle of joint I; antennal joint I curve, slightly wider than joint II; antennal joints II and III cylindrical; antennal joint IV fusiform; rostrum long, slightly passing base of metacoxa. Pronotum with short collar after head, followed by narrow anterior band; short black setae present on pronotum, more abundant on anterior band; posterior band of pronotum with weak central elevation, slightly depressed near humeri; humeri weakly elevated with margin rounded; posterior margin of pronotum straight; scutellum rounded and covered by short black setae; metanotal elevation with posterior margin rounded; forewing with two elongated proximal cells, with no distal cell; short black setae covering forewing veins, more abundant on outer margin; unbroken wings passing apex of genital segments; legs thin, covered by short brown setae and robust black setae near apex of femora (one on forefemur, one or two on midfemur, and one or two on hindfemur (Figs. 2, 5 and 8: RST); femora without spines; foretibia and midtibia with many long brown setae on apical third (Figs. 2 and 5: LST); hindtibia with long black spines throughout its extension (Fig. 8: SPI). Abdominal tergites VII and VIII with posterior margin rounded; venter of pre-genital abdomen glabrous, unless by short brown setae on lateral areas; abdominal sternite VI with fringe of more or less twenty black spinules near posterior margin (Fig. 6: FRI); abdominal sternite VIII without spines (Fig. 6); long setae on posterior half of abdominal sternite VIII (Fig. 6: LST); proctiger with weak central carina, without lateral expansions (Fig. 10: CAR); numerous long light setae present on apical portion of proctiger (Fig. 10: LST); posterior margin of proctiger rounded; pigophore with long setae on apical portion; claspers symmetrical and glabrous (Fig. 10: CLA); clasper (Fig. 12), in dorsal view, with widened base; inner margin of clasper with basal concavity, curving into a "C" to acute apex; outer margin of clasper strongly curved after half.

Macropterous female

Body length - 2.01-2.30; body width across humeri$0.66-0.73$; head length in lateral view-0.50-0.53; head width across eyes- $0.48-0.50$; length of antennal joints (intersegmental pieces not included): I-0.29-0.34, II-0.190.25 , III-0.54-0.61, IV—0.59-0.63; minimum interocular distance $-0.21-0.24$; eye width $-0.13-0.14$; length of pronotum on midline $-0.36-0.40$; wing length $-1.50-1.53$; foreleg length: femur $-0.46-0.50$, tibia $-0.46-0.50$, tarsomerus I- 0.04 , tarsomerus II -0.06 , tarsomerus III0.09-0.10; midleg length: femur $-0.59-0.63$, tibia -0.63 , tarsomerus I- 0.04 , tarsomerus II $-0.08-0.09$, tarsomerus III-0.09-0.13; hindleg length: femur $-0.75-0.88$, tibia0.99-1.06, tarsomerus I-0.04, tarsomerus II $-0.13-0.14$, tarsomerus III-0.13-0.14.

Similar to male in coloration pattern, but generally darker. Also similar in structure, except for one or two robust setae on antennal joint I always with two robust setae on midfemur and hindfemur; absence of fringe on abdominal sternite VI; and presence of serrate ovipositor.

\section{Comments}

According to Harris e Drake (1941), the body length of M. zeteki is $2.45 \mathrm{~mm}$, alate males always larger than alate females of $M$. amoena, a similar species. Like $M$. mulsanti, no significant differences in measurements were found between specimens with wings broken off or unbroken. The length of broken wings ranged from 0.89 to $0.93 \mathrm{~mm}$.

Diagnostic male features of $M$. zeteki include forefemur and midfemur without spines (Fig. 2 e 5), presence of fringe of spinules near posterior margin of abdominal sternite VI (Fig. 6: FRI), and absence of spines on abdominal sternite VIII.

\section{Notes on biology}

There is no expressive information on the biology of this species available and no life cycle study was made so far. Type-material of the species was collected on the shores of a stream in Panama.

Unlike M. mulsanti, most of the observed material of the species was collected in light traps, showing high attraction to light and an elevated proportion of full winged individuals in the studied populations.

\section{Distribution (Fig. 15)}

The species was previously known from Panama (Harris e Drake, 1941) and Brazil (Drake e Harris, 1946).

Distribution in Brazil: Pará - Almerim!, Juriti!, Prainha!, Santarém!, Amazonas -Itacoatiara!.

\section{Examined material}

BRAZIL: Pará - Almerim, Nova Aramanduba, 07.X.2003, (P. de Marco \& N. Ferreira-Jr.): 1 macropterous male (INPA) [lago, -1,17777 $-51,79407^{\circ}$ ]; Paraná do Tauaçuí, 08.X.2003: 1 macropterous male and 1 macropterous female (DZRJ) [paraná, luz UV, -1,17995 / -51,79561']; Paranaquara, 05.X.2003: 1 female with broken wings (INPA) [lake in Paranaquara, $\left.-1,74198^{\circ} /-53,17167^{\circ}\right] ; 1$ macropterous female (DZRJ) [paraná, boat, UV light trap]. Juriti, Recreio, 26.IX.2003, (P. de Marco \& N. Ferreira-Jr.): 1 female with broken wings (INPA) [Recreio Lake, $-2,06607^{\circ} /-55,95935^{\circ}$; 1 macropterous female (DZRJ) [Paraná, UV light trap, $-2,06549^{\circ} /-55,56264^{\circ}$. Prainha, Capiranga, 02.X.2003, (P. de Marco \& N. Ferreira-Jr.): 1 female with broken wings (INPA) [Mureru Lake, -2,38959 / -54,08131 ${ }^{\circ}$; 10 macropterous males and 14 macropterous females (DZRJ) [Mureru Lake, UV Light Trap, -2,38959 / -54,08131º]; 

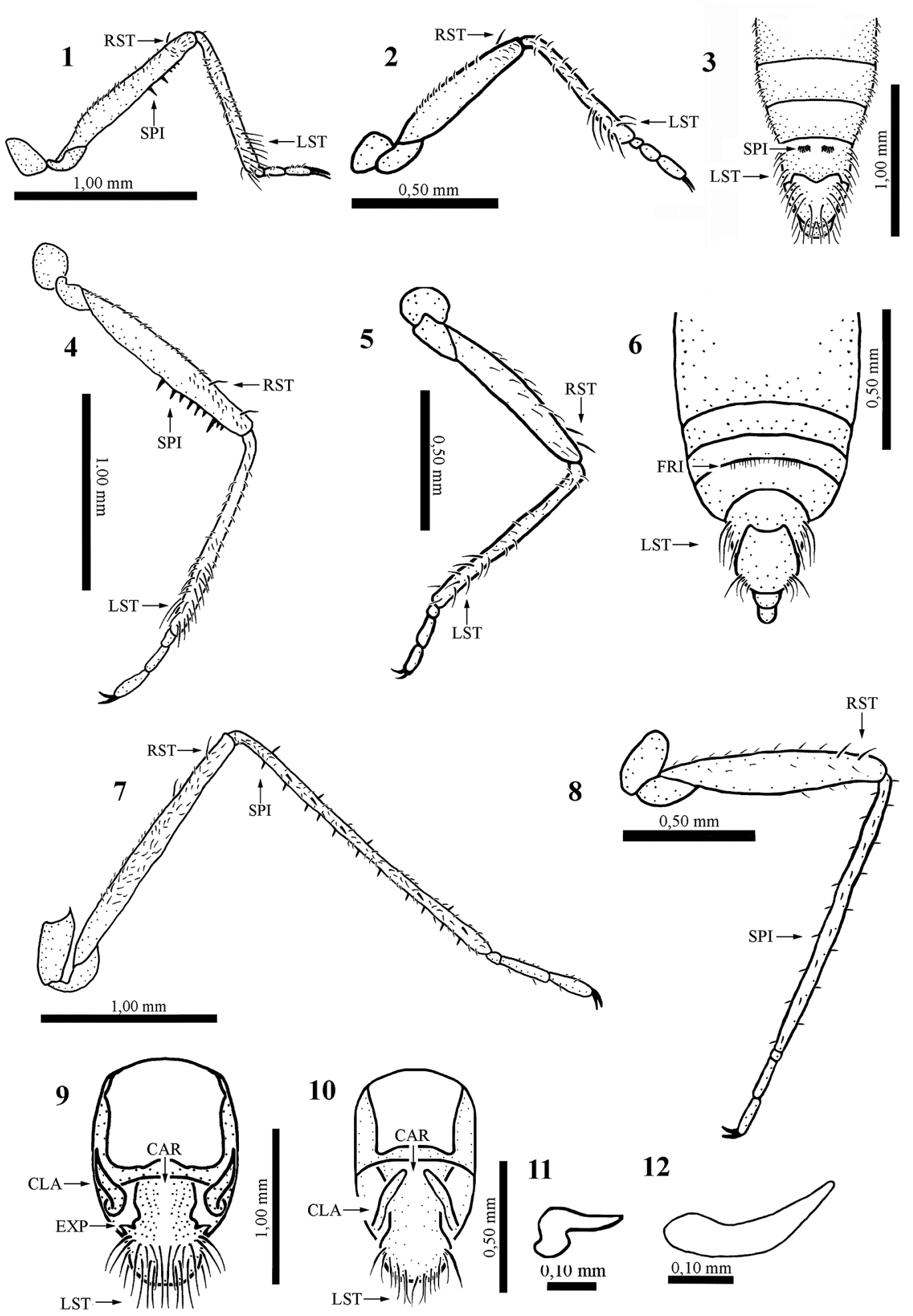

12

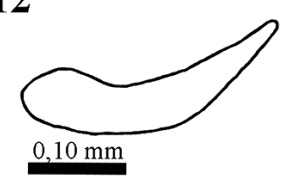

Plate I: Figures 1, 3, 4, 7, 9, 11 - Mesovelia mulsanti, male. Figures 2, 5, 6, 8, 12 - Mesovelia zeteki, male. Figures 1, 2 - foreleg. Figures 3, 6 - apex of abdomen, ventral view. Figures 4, 5 - midleg. Figures 7, 8 - hindleg. Figures 9, 10, genital segments, dorsal view. Figures 11, 12 - claspers, dorsal view (CAR - carina; CLA - clasper; EXP - expansion; FRI - fringe of spinules; LST - long setae; RST - robust setae; SPI - spines). 
13

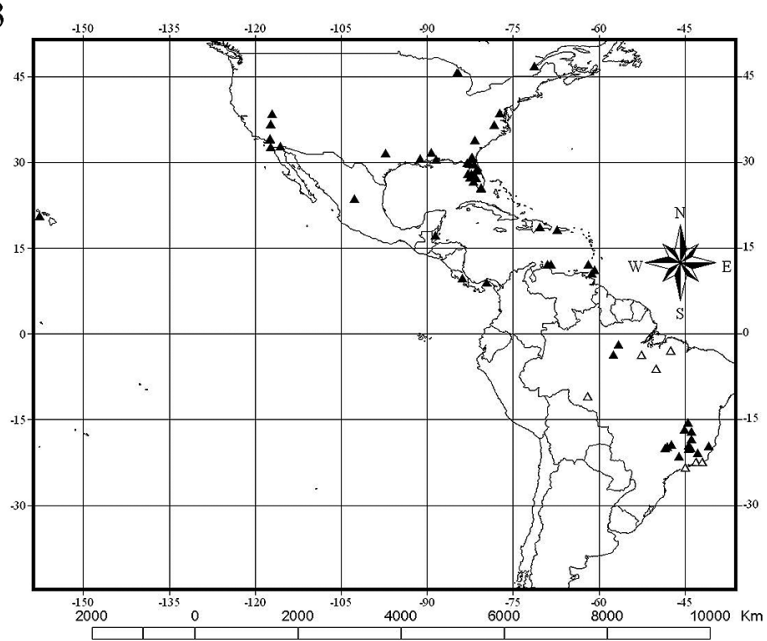

14

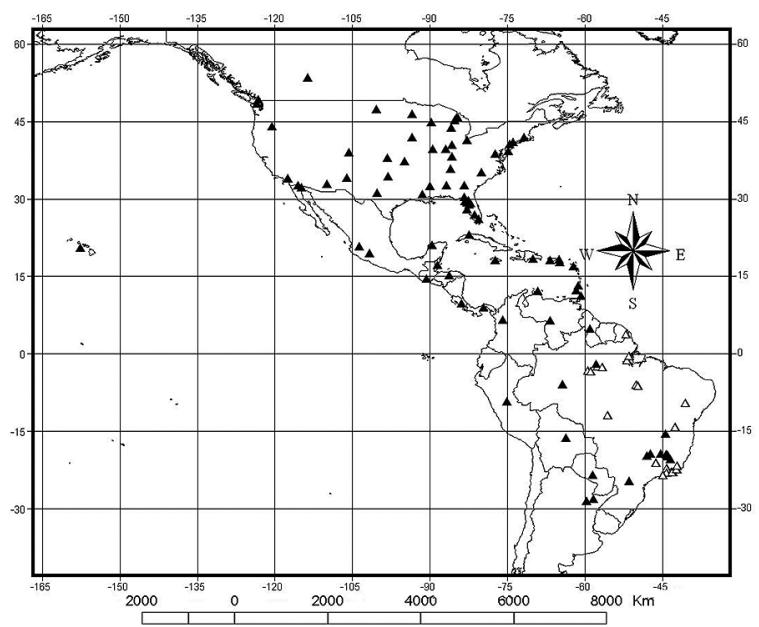

15

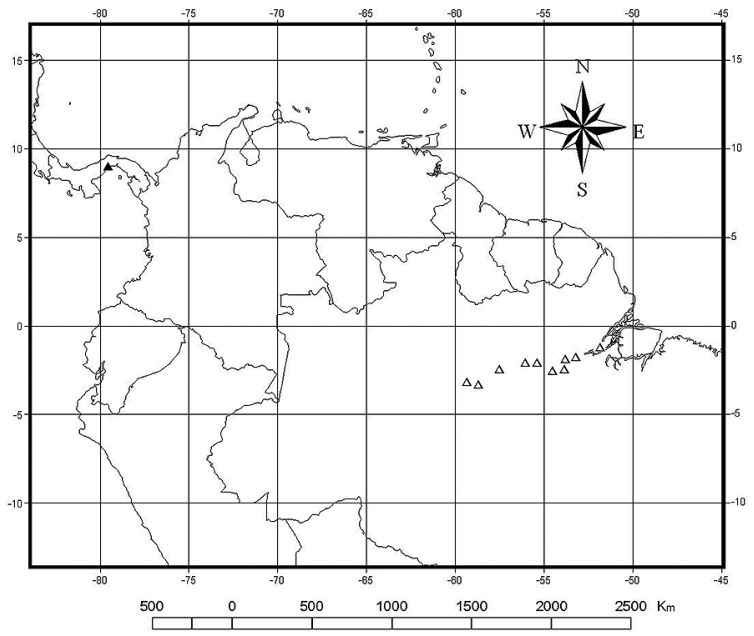

Plate II: Figure 13 - geographic distribution of Mesovelia amoena. Figure 14 - geographic distribution of Mesovelia mulsanti. Figure 15 - geographic distribution of Mesovelia zeteki (new records shown by white triangles).
Retiro JK, 04.X.2003: 8 females with broken wings (INPA) [Retiro JK Lake, $-1,85557^{\circ}-53,71524^{\circ}$ ]; 1 macropterous male and 1 macropterous female (INPA) [barco, luz UV, $-1,85986^{\circ} /$ $\left.-53,71148^{\circ}\right]$. Santarém, Santana do Ituqui, 30.IX.2003, (P. de Marco \& N. Ferreira-Jr.): 1 female with broken wings (INPA) [Lago Maicá, -2,51221 / -54,32885 ${ }^{\circ}$; 1 macropterous male, 3 macropterous females (DZRJ) [Lago Maicá, luz $U V$, $-2,51221^{\circ} /-54,32885^{\circ}$. Amazonas - Itacoatiara, Ilha da Trindade, 22.IX.2003, (P. de Marco \& N. Ferreira-Jr.): 1 female with broken wings (INPA) [lake in Ilha da trindade, $\left.-3,32478^{\circ} /-58,74241^{\circ}\right] ; 2$ macropterous femaes (INPA) [Paraná da Trindade, luz UV, -3,31345 / -58,73231 ${ }^{\circ}$; 1 macropterous female (INPA) [Paraná da Trindade, barco, luz $U V,-3,31345^{\circ} /-58,73231^{\circ}$ ]; Nossa Senhora do Perpétuo Socorro, 21.IX.2003: 2 macropterous females (INPA) [Traíra Lake, UV light trap, $-3,159975^{\circ} /-59,32716^{\circ}$ ]; Paraná da Trindade, Lírio do Vale, 24.IX.2003: 9 macropterous males and 53 macropterous females (DZRJ) [Albano lake, UV light trap, $-2,41418^{\circ} /-57,49993^{\circ}$ ]; 4 macropterous females (INPA) [Albano lake, boat, UV light trap, -2,41418 / -57,49993º].

\section{Key to species of adult Mesovelia occurring in the floodplain of the Amazon River}

1a - Body length larger than $2.50 \mathrm{~mm}$, at most $4.00 \mathrm{~mm}$; head uniformly dark yellow without longitudinal brown stripes near midline; pronotum width of macropterous individuals greater than $0.80 \mathrm{~mm}$; forefemur and midfemur of the male with ventral row of spines (Fig. 1 and 4: SPI); abdominal sternite VIII of male with two tufts of sharp black spines densely grouped (Fig. 3: SPI) M. mulsanti $1 \mathrm{~b}$ - Body length less than $2.50 \mathrm{~mm}$; head yellow with two longitudinal brown stripes near midline; pronotum width of macropterous individuals at most $0.75 \mathrm{~mm}$; femora without spines; abdominal sternite VIII of male without spines .... 2 $2 \mathrm{a}-$ Body yellow; pronotum of alate individuals with anterior lobe lacking depressions and posterior margin straight; abdominal sternite VI of male with fringe of about twenty black spinules near posterior margin (Fig. 3: FRI)

M. zeteki

$2 \mathrm{~b}$ - Body dark brown, almost black in some specimens; pronotum of alate individuals with anterior lobe depressed on each side of median line and posterior margin sinuous; abdominal strenite VI without spines M. amoena

\section{ACKNOWLEDGEMENTS}

The manuscript benefited from the useful comments of A. L. Carvalho. This study was supported by Programa PróVárzea (IBAMA), through the project "Bases Científicas para Conservação da Várzea”, by Fadesp and by CNPq. 


\section{REFERENCES}

Andersen, N.M.; Polhemus, J.T. 1980. Four new genera of Mesoveliidae (Hemiptera, Gerromorpha) and the phylogeny and classification of the family. Entomologica Scandinavica, 11: 369-392.

Bass, D. 2003. A survey of freshwater macroinvertebrates in Tobago. Living World, Journal of Trinidad and Tobago Field Naturalists' Club, 2003: 64-69.

Barber, H.G. 1923. A preliminary report on the HemipteraHeteroptera of Porto Rico collected by the American Museum of Natural History. American Museum Novitates, 75: 1-13.

Blatchley, W.S. 1926. Heteroptera or True Bugs of Eastern North America with Especial Reference to the Faunas of Indiana and Florida. The Nature Publishing Company, Indianapolis. 1116p.

Carvalho, J.C.M. 1984. On a new species of intertidal water strider from Brazil (Hemiptera, Gerromorpha, Mesoveliidae). Amazoniana, 8: 519-523.

Champion, G.C. 1898. Hemiptera - Heteroptera. Biologia CentraliAmericana. Rhynchota, 2: 1-416.

Chapman, H.C. 1959. Distributional and ecological records for some aquatic and semi-aquatic Heteroptera of New Jersey. Bulletin of the Brooklyn Entomological Society, 54: 8-12.

Cobben, R.H. 1960. The Heteroptera of the Netherland Antilles. I. Foreword - Gerridae, Veliidae, Mesoveliidae. Studies on the Fauna of Curaçao and other Caribbean Islands, 11: 1-34.

Distant, W.L. 1910. Heteroptera: Appendix. The Fauna of British India, Including Ceylon and Burma. Rhynchota, 5: 1-353.

Drake, C.J.; Harris, H.M. 1946. A new mesoveliid from Ecuador (Hemiptera, Mesoveliidae). Bulletin of the Brooklyn Entomological Society, 41: 8-9.

Gagné, W.C.; Howarth, F.G. 1975. The cavernicolous fauna of Hawaiian lava tubes, 6. Mesoveliidae or water treaders. Pacific Insects, 16: 399-413.

Goulding, M.; Barthem, R.B.; Ferreira, E.J.G. 2003. The Smithsonian Atlas of the Amazon. Smithsonian Institution, Washington. 253 pp.

Harris, H.M.; Drake, C.J. 1941. Notes on the family Mesoveliidae (Hemiptera) with descriptions of two new species. Iowa State College Journal of Science, 15: 275-277.

Herring, J.L. 1950. The aquatic and semiaquatic hemiptera of Northern Florida, Part 2: Veliidae and Mesoveliidae. The Florida Entomologist, 33: 145-150.

Hoffman, C.H. 1932. The biology of three North American species of Mesovelia (Hemiptera - Mesoveliidae). The Canadian Entomologist, 64: 88-95, 113-120, 126-134.

Hungerford, H.B. 1917. The life history of Mesovelia mulsant $i$ White. Psyche, 24: 73-83.

Hungerford, H.B. 1919. The biology and ecology of aquatic ad semiaquatic Hemiptera. The Kansas University Science Bulletin, 11: $1-328$.

Hungerford, H.B. 1924. A new Mesovelia with some biological notes regarding it. Canadian Entomologist, 56: 142-144.
Hungerford, H.B. 1936. Aquatic and semiaquatic Hemiptera collected in Yucatan and Campeche. pp. 145-150. In: Pearse, A.; Creaser, E. (eds.). The Cenotes of Yucatan: a zoological and hydrographic survey. Carnegie Institute of Washington Publications, 157.

Hungerford, H.B. 1953. Concerning Mesovelia douglaensis Hungerford. Journal of the Kansas Entomological Society, 26: 76-77.

Jaczewski, T. 1928. Mesoveliidae from the State of Paraná. Annales Musei Zoologici Polonici, 7: 75-80, prancha IV.

Jaczewski, T. 1930. Notes on the American species of the genus Mesovelia Muls. (Heteroptera, Mesoveliidae). Annales Musei Zoologici Polonici, 9: 1-12, pranchas I-III.

Jordan, K.H.C. 1951. Autotomie bei Mesovelia furcata. Zoologischer Anzeiger, 147: 205-209.

Kirkaldy, G.W.; Torre-Bueno, J.R. de la. 1909. A catalogue of American aquatic and semi-aquatic Hemiptera. Proceedings of the Entomological Society of Washingtoni, 10: 173-213.

Larsen, E.; Olson, C. 1997. Aquatic Coleoptera and Hemiptera of Organ Pipe Cactus National Monument, Arizona. Entomological News, 108: 34-42.

López-Ruf, M.L.; Mazzucconi, S.A.; Bachmann, A.O. 2003. Heteroptera acuáticos y semiacuáticos del Parque Nacional Mburucuyá (Provincia de Corrientes, Argentina). Revista de la Sociedad Entomologica Argentina, 62: 65-71.

Melo, A.L.; Nieser, N. 2004. Faunistical notes on aquatic Heteroptera of Minas Gerais (Brazil): an annotated list of Gerromorpha and Nepomorpha collected near Januária, MG. Lundiana, 5: 43-49.

Moreira, F.F.F.; Ribeiro, J.R.I.; Nessimian, J.L. 2006. Description of the male and the southernmost record of Mesoveloidea williamsi Hungerford, 1929 (Hemiptera: Heteroptera: Mesoveliidae). Zootaxa, 1269: 51-56.

Moretti, E.; Francelino, M.R. 2003. Curso básico de ArcView 3.2. Apostila. (geoflora.googlepages.com/arcview.pdf). Access: 03/18/2008.

Neering, T. 1954. Morphological variations in Mesovelia mulsanti (Hemiptera, Mesoveliidae). The University of Kansas Science Bulletin, 36: 125-148.

Nessimian, J.L.; Hamada, N.; Ferreira-Jr, N.; De Marco-Jr, P. 2004. Sub-estudo Entomofauna Aquática - Bases cientificas para a conservação da várzea: Identificação e caracterização de regiōes biogeográficas. PROVÁRZEA/IBAMA, Relatório Técnico.

Nieser, N.; Melo, A.L. 1997. Os Heterópteros Aquáticos de Minas Gerais, Guia Introdutório com Chave de Identificação para as Espécies de Nepomorpha e Gerromorpha. Editora UFMG, Belo Horizonte. 180pp.

Osborn, H.; Drake, C.J. 1915. Additions and notes on the Hemiptera-Heteroptera of Ohio. The Ohio Naturalist, and Journal of Science, 15: 501-508.

Pereira, D.L.V. 2004. Distribuição e Chave Taxonômica de Gêneros de Gerromorpha e Nepomorpha (Insecta: Heteroptera) na Amazônia Central, Brasil. Master thesis, Instituto Nacional de Pesquisas 
da Amazônia/Fundação Universidade do Amazonas, Manaus, Amazonas, 141pp.

Pérez, G.R. 1988. Guía para el Estudio de los Macroinvertebrados Acuáticos del Departamento Antioquia. Universidad de Antioquia, Bogotá. xi+217pp.

Poi de Neiff, A.; Neiff, J.J. 2006. Riqueza de especies y similaridad de los invertebrados que viven en plantas flotantes de la planicie de inundación del Rio Paraná (Argentina). Interciencia, 31: 220-225.

Polhemus, J.T.; Chapman, H.C. 1979. Family Mesoveliidae/water treaders. pp. 39-42 in: Menke, A.S. (ed.). The Semiaquatic and Aquatic Hemiptera of California (Heteroptera: Hemiptera). Bulletin of the California Insect Survey, 21: 1-166.

Souza, M.A.A.; Melo, A.L.; Vianna, G.J.C. 2006. Heterópteros aquáticos oriundos do Município de Mariana, MG. Neotropical Entomology, 35: 803-810.

Spangler, P.J. 1990. A new species of halophilous water-strider, Mesovelia polhemusi, from Belize and a key and checklist of the New World species of the genus (Heteroptera: Mesoveliidae). Proceedings of the Biological Society of Washington, 103: 86-94.

Uhler, P.R. 1884. Order IV. Hemiptera in: Kingsley, J. The Standard Natural History, vol 2. Cassino \& Co., Boston. vii+555p.

Uhler, P.R. 1893. A list of Hemiptera-Heteroptera collected in the island of St. Vincent by Mr. Herbert H. Smith, with description of new genera and species. Proceedings of the Zoological Society of London, 1893: 705-719.
Uhler, P.R. 1894a. On the Hemiptera - Heteroptera of the Island of Grenada, West Indies. Proceedings of the Zoological Society of London, 1894: 167-224.

Uhler, P.R. 1894b. Observations upon the heteropterous Hemiptera of Lower California, with descriptions of new species. Proceedings of the California Academy of Sciencesi, (2)4: 223-295.

Usinger, R.L. 1942. Notes on the variation of Mesovelia mulsanti White (Mesoveliidae, Hemiptera). Bulletin of the Brooklyn Entomological Society, 37: 177-178.

Vianna, G.J.C.; Melo, A.L. 2003. Distribution patterns of aquatic and semi aquatic Heteroptera in Retiro das Pedras, Brumadinho, Minas Gerais, Brazil. Lundiana, 4: 125-128.

White, F.B. 1879. List of the Hemiptera collected in the Amazons by Prof. J. W. H. Trail, MA., M.D., in the years 1873-1875, with descriptions of the new species. Transactions of the Royal Entomological Society of London, 4: 267-276.

Zimmermann, M.; Spence, R. 1989. Prey use of the fishing spider Dolomedes triton (Pisauridae, Araneae): an important predator of the neuston community. Oecologia, 80: 187-194.

Zuellig, R.E.; Kondratieff, B.C.; Schmidt, J.P.; Durfee, R.S.; Ruiter, D.E.; Prather, I.E. 2006. An annotated list of aquatic insects of Fort Sill, Oklahoma, excluding Diptera with notes on several new state records. Journal of the Kansas Entomological Society, 79: 35-54.

Recebido em 13/12/2007

Aceito em 13/03/2008 
